Kirenko, J. (2021). W stronę normalności. W: E. DomagAŁA-Zyśk i wsp. (red.), Oblicza życia. Księga jubileuszowa Profesor Doroty Kornas-Bieli (s. 699-713). Lublin: Episteme.

KrakowiaK, K. (2021). Nad językiem i dziełem profesor Doroty Kornas-Bieli (refleksje polonistki. W: E. DomagaŁa-ZyśK i wsp. (red.), Oblicza życia. Księga jubileuszowa Profesor Doroty Kornas-Bieli (s. 992-995). Lublin: Episteme.

PóŁtawska, W. (2021). Radykalizm i realizm wiary w rodzinie. W: E. DomagaŁA-Zyśk i wsp. (red.), Oblicza życia. Księga jubileuszowa Profesor Doroty Kornas-Bieli (s. 391-402). Lublin: Episteme.

Ryś, M., TaAtaj-Puzyna, U. (2021). Życie i miłość są silniejsze od śmierci. Znaczenie postawy szacunku dla życia w budowaniu cywilizacji miłości. W: E. DomaGAŁA-Zyśk i wsp. (red.), Oblicza życia. Księga jubileuszowa Profesor Doroty Kornas-Bieli (s. 199-218). Lublin: Episteme.

STEUDEN, S. (2021). Kilka refleksji o czasie i mądrości z perspektywy człowieka w późnej starości. W: E. DomagaŁA-ZYśK i wsp. (red.), Oblicza życia. Księga jubileuszowa Profesor Doroty Kornas-Bieli (s. 481-496). Lublin: Episteme.

Wilczek, M., (2021). Opowiedz nam o swoim życiu. W: E. DomagaŁa-Zyśk i wsp. (red.), Oblicza życia. Księga jubileuszowa Profesor Doroty Kornas-Bieli (s. 133-167). Lublin: Episteme.

ZawadA, M., (2021). Dwie metafory życia osadzonego w Bogu. W: E. DomagaŁA-ZYśk i wsp. (red.), Oblicza życia. Księga jubileuszowa Profesor Doroty Kornas-Bieli (s. 497-526). Lublin: Episteme.

Mgr Agnieszka Amilkiewicz-Marek e-mail: agnieszka.amilkiewicz-marek@kul.pl Mgr Urszula Kmita e-mail: urszula.kmita@kul.pl

\title{
Magdalena GIERCARZ-BORKOWSKA, Edukacja domowa jako alternatywa edukacyjna dla dzieci zdolnych, Wrocław: Wydawnictwo TestTy, 2019.
}

DOI: http://doi.org/10.18290/rped.21133.11

Przedmiotem niniejszej recenzji jest książka poświęcona edukacji domowej, będącej alternatywną ścieżką rozwoju dla dzieci zdolnych. Pozycja jest opublikowaną rozprawą doktorską, obronioną na Wydziale Nauk Pedagogicznych Dolnośląskiej Szkoły Wyższej we Wrocławiu w 2017 roku.

Książka składa się z czterech rozdziałów. Trzy pierwsze stanowią teoretyczne ujęcie zagadnień związanych z uczniem zdolnym, edukacją domową oraz podejmowanymi w pracy doktorskiej badaniami. Ostatni, czwarty rozdział stanowi natomiast analizę prowadzonych przez autorkę badań. 
Pierwszy rozdział (s. 17-88), poświęcony funkcjonowaniu ucznia zdolnego, zawiera przekrój definicji oraz koncepcji zdolności. Autorka na potrzeby pracy wskazuje najbliższe jej rozumienie mające charakter potencjalny, które odnaleźć można w Monachijskim Modelu Zdolności i Talentu Hellera oraz w Modelu Różnicującym Zdolności i Talent Gagné'a. W rozdziale tym autorka pochyla się nad problemem potrzeb edukacyjnych dzieci zdolnych oraz asynchronicznym rozwojem tych dzieci. Ostatnią składową rozdziału jest przedstawienie sytuacji uczniów zdolnych w rzeczywistości polskiej oświaty (zarówno pod kątem praktyki pedagogicznej, jak i prawodawstwa).

Drugi rozdział (s. 103-158) poświęcony jest zagadnieniu edukacji domowej: jej rysowi historycznemu, podstawom prawnym, motywacjom rodziców edukujących domowo oraz postawom społecznym rodzącym się wobec edukacji domowej.

Kolejny rozdział (s. 167-200) stanowi wstęp do badań naukowych. Autorka wskazuje w nim motywy doboru problematyki badawczej oraz precyzyjnie określa metodę badawczą, którą posłużyła się w niniejszej publikacji. Ostatni rozdział (s. 205-416) stanowi prezentację wyników badań.

Podjęte przez autorkę badania zorientowane są humanistycznie i mieszczą się w tradycji badań jakościowych. Badaczka posłużyła się w nich techniką wywiadu narracyjnego, a całą procedurę analizy zebranego materiału oparła na procesie indukcji (przejście od praktyki do teorii). Grupę badaną (49 osób) stanowili zarówno rodzice jak i dzieci praktykujący edukację domową. Celem postawionym przez autorkę było ,opisanie zjawiska edukacji domowej w kontekście specjalnych potrzeb edukacyjnych uczniów zdolnych [...] Ze względu na ten cel i intencję badania miały charakter praktyczny i powinny służyć praktyce edukacyjnej” (s. 178-179).

Niniejsza publikacja spełnia wyznaczony przez autorkę cel. Wnikliwa analiza pozyskanego w wyniku badań materiału umożliwia wyróżnienie wielu aspektów edukacji domowej, które mogą działać na korzyść uczniów zdolnych. Zawarte w pracy wypowiedzi rodziców ukazują różnorodne i odmienne podejście do prowadzenia swoich dzieci. Każdą z tych wypowiedzi cechuje indywidualne podejście do dziecka, objawiające się doborem odpowiednich metod, poziomu zadań, źródeł i narzędzi wykorzystywanych w procesie edukacji. Wymieniane przez dzieci i rodziców zalety i wady edukacji domowej pozwalają wyłonić cechy, które mogą wpływać korzystnie w pracy z uczniem zdolnym. Alternatywny i kameralny sposób edukacji zostaje w tej książce ujawniony i szczegółowo opisany z perspektyw osób w różnym wieku i pozycji społecznych.

Zarzutem, jaki można podnieść w stosunku do autorki, jest brak obiektywności. Podczas lektury czytelnik ma możliwość zestawienia i porównania dwóch rodzajów edukacji: szkolnej i domowej. Z czego edukacja szkolna przedstawiana jest w głównej mierze w negatywnym świetle. W kontraście do tego z wyników badań wyłania się obraz przepełniony atutami, jakie niesie za sobą edukacja domowa. Czytelnik może zarzucić stronniczość w doborze dowodów, które wskazują nie tylko na fakt, iż edu- 
kacja domowa jest alternatywną ścieżką rozwoju dzieci zdolnych, ale także wartościuje tę ścieżkę jako lepszą.

Mimo postawionych zarzutów, opisywana publikacja stanowi ważną pozycję w piśmiennictwie pedagogicznym, gdyż jako nieliczna podejmuje temat edukacji domowej. Edukacja domowa w Polsce nadal jest tematem niszowym, choć coraz więcej rodzin decyduje się na taką ścieżkę rozwoju swoich dzieci. Publikacja stanowi kompendium wiedzy dla takich rodzin ponieważ wskazuje metody, środki i narzędzia z jakich można korzystać, żeby w jak najlepszy sposób wspomóc rozwój dzieci, nie tylko tych wykazujących ponadprzeciętne zdolności.

Dominika Wierzbicka Studentka KUL e-mail:w.wierzbickadominika@gmail.com

Janusz MARIAŃsKi, Godność ludzka w narracji spotecznej. Studium socjopedagogiczne, Lublin: Wydawnictwo KUL, 2021, ss. 299.

DOI: http://doi.org/10.18290/rped.21133.12

Ksiądz profesor dr hab. Janusz Mariański odznaczony tytułem doktora honoris causa Uniwersytetu Śląskiego, najwyższą godnością akademicką, którą otrzymują tylko wybitne osobowości świata nauki, jest autorem kolejnej publikacji Godność ludzka $w$ narracji społecznej. Studium socjopedagogiczne. Jako socjolog religii, socjolog moralności i znawca katolickiej nauki społecznej Kościoła, podejmuje w niej relewantne zagadnienia w wymiarze interdyscyplinarnym. Zanim przejdę do omówienia niniejszej monografii, najpierw skieruję uwagę na niektóre kwestie związane z godnością osoby ludzkiej, które podejmowane są aktualnie w różnych gremiach naukowych.

Godność człowieka jest mocno zakorzeniona w Ustawach Zasadniczych różnych państw. W polskiej Konstytucji art. 30 stanowi o godności człowieka - Przyrodzona i niezbywalna godność człowieka stanowi źródto wolności praw człowieka i obywatela $i$ jest ona nienaruszalna i jej poszanowanie i ochrona jest obowiazkiem władz publicznych. Pomimo tego zakorzenienia w Konstytucji, godność człowieka jest bardzo często przedmiotem kontrowersji w dyskursie publicznym. Stawiane są pytania, czy jest to naprawdę nienaruszalna wartość i czy w niektórych skrajnych przypadkach ograniczanie jej nie powinno być dozwolone na korzyść innych centralnych wartości?

Historia godności człowieka, jako koncepcji etycznej, zaczyna się od rzymskiego polityka i filozofa Cycerona. W pierwszym wieku przed Chrystusem był pierwszym myślicielem, który przypisał człowiekowi szczególne miejsce wyłącznie na podstawie jego talentu rozumowego. Jednak Cyceron uważa, że godność należy zdobyć najpierw 